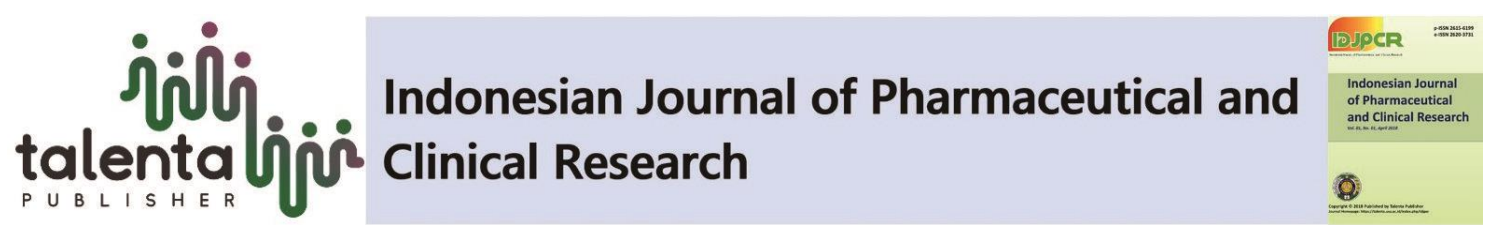

\title{
Effect of Adherence with Clinical Outcomes and Quality of Life Primary Hypertension Patients in Pharmacy
}

\author{
Dumartina Hutauruk, Khairunnisa, and Wiryanto \\ Department of Pharmacology, Faculty of Pharmacy, Universitas Sumatera Utara, Medan, Indonesia
}

\begin{abstract}
This study aimed to examine the effect of adherence to clinical outcomes and the quality of life of primary hypertension patients in pharmacy. The studywas conducted cross sectionally involved 60 patients at one of the pharmacies in Medan, Indonesia. Adherence was obtained in the form of adherence levels measured using the MMAS-8 questionnaire, clinical outcomes assessed by measuring a patient's blood pressure, and quality of life assessed using the EQ-5D-3L questionnaire. Then the data were analyzed using the Spearmen rho test. Patients who participated in the study consisted of 24 men and 36 women. Almost patient has low adherence with blood pressure mean of $156 / 90 \mathrm{mmHg}$. The patient's quality of life was $77.7 \%$. Adherence has a significant relationship to clinical outcomes $(\mathrm{p}<0.05)$ with a strong correlation of $\mathrm{r}=-0.745$. Adherence has a relationship to quality of life $(\mathrm{p}<0.05)$ with moderate correlation $\mathrm{r}=0.554$. This study concluded that adherence has a correlation with clinical outcomes and the quality of life of primary hypertension patients.
\end{abstract}

Keyword: Adherence, Hypertension, Pharmacy, Quality of life.

\begin{abstract}
Abstrak. Penelitian ini bertujuan untuk mengkaji pengaruh kepatuhan terhadap outcome klinis dan kualitas hidup pasien hipertensi primer di Apotek. Penelitian dilakukan secara cross sectional dengan melibatkan 60 pasien di salah satu apotek di kota Medan, Indonesia. Data kepatuhan diperoleh dalam bentuk tingkat kepatuhan yang diukur menggunakan kuesioner MMAS-8, outcome klinis dinilai dengan mengukur tekanan darah pasien, dan data kualitas hidup dinilai menggunakan kuesioner EQ-5D-3L. Kemudian data dianalisis menggunakan uji Spearmen rho. Pasien yang mengikuti penelitian terdiri dari 24 laki-laki dan 36 perempuan. Rata-rata pasien memiliki kepatuhan rendah dengan tekanan darah rata-rata sebesar 156/90 mmHg. Kualitas hidup pasien rata-rata diperoleh sebesar $77,7 \%$. Kepatuhan memiliki hubungan yang signifikan terhadap outcome klinis $(p<0,05)$ dengan korelasi kuat $r=-0,745$. Kepatuhan juga memiliki korelasi terhadap kualitas hidup $(p<0,05)$ dengan korelasi cukup $r=0.554)$. Penelitian ini menyimpulkan bahwa kepatuhan pengobatan mempunyai korelasi dengan outcome klinis dan kualitas hidup pasien hipertensi primer.
\end{abstract}

Kata Kunci: Adherence, Hypertension, Pharmacy, Quality of life.

Received 12 December 2020 | Revised 8 January 2021 | Accepted 10 January 2021

\footnotetext{
*Corresponding author at: Department of Pharmacology, Faculty of Pharmacy, Universitas Sumatera Utara, Medan, Indonesia 


\section{Introduction}

Data from WHO in 2017 showed that there were 17.9 million people in the world who died from cardiovascular disease or about $31 \%$ of the total deaths worldwide [1]. Hypertension is one of the risk factors for cardiovascular disease. In 2015, an increase in blood pressure resulted in 9.4 million deaths and was a disease that increased Disability-Adjusted Life Years [2]. WHO data for 2019 estimated that at least 1.13 billion people in the world suffer from hypertension.

The treatment of hypertension in Asian countries is very important because the prevalence of hypertension continuesly to increase, including in Indonesia [3]. Indonesia Basic Health Research in 2018 reported that the number of hypertension patients increased from $25.8 \%$ in 2013 to $34.1 \%$ in 2018 based on blood pressure measurements in the age group 18 and older [4].

High quality medicines are already widely prescribed for patients, but there are more than $50 \%$ of non-adherence patients. In asimptomatic diseases such as hypertension, the non-adherence can reach $80 \%$ [15]. Low levels of patient adherence to treatment of hypertension are the main problems of complications, decreased effectiveness of treatment, and resulting in increased mortality [6], [8]. Non-adherence lead to uncontrolled blood pressure. In United States, only $50 \%$ of patients had controlled their blood pressure. Non-adherence patients are more likely to experience of cardiovascular complications indeed death compared with the adherence patients [9]. Some factors affected non-adherence were reported by several studies, including age, presence or absence of comorbid diseases, number of medicines taken, and patients knowledge [10], [11], [12]. The patient quality of life is also influenced by factors related to physical, emotional, social conditions as well as factors related to medication treatment [13]. Hypertension also related to quality of life. Patients with hypertension tend to have a poor quality of life compared to patients with normal blood pressure [14], [15]. The poor quality of life due to they have the risk of complications and adverse effects form medicines. The main factor affected the quality of life of hypertensive patients are mental and emotional conditions [14].

There are several studies related to adherence and the quality of life of hypertensive patients, but very limited data is obtained from pharmacies. This study aimed to examine the effect of adherence to clinical outcomes and the quality of life of primary hypertension patients in pharmacy.

\section{Material and Methods}

\subsection{Patients and study design}

This was an observational study through cross sectional design in one of pharmacies in Medan, North Sumatera, Indonesia on July-Augustus 2020. The study was conducted on hypertensive 
patients who were redeemed the medical prescription at the pharmacy and meet the inclusion criteria (patient diagnosed with primary hypertension more than 2 months, aged older than 18 years, and signed the inform consent. This study has been approved by the Ethical Committee of the Health Research, Faculty of Nursing, Universitas Sumatera Utara No. 2175/VII/SP/2020.

\subsection{Measurement of adherence by MMAS-8, clinical outcome, and quality of life}

Adherence was measured by the 8-item Morisky Medication Adherence Scale (MMAS-8) questionnaire. The study used MMAS-8 version of Indonesia contained 8 questions with closed dichotomous (yes/no) answer. The questionnaire has been validated with high reliability and validity well [16]. Respons of the questions were scored from 0 to 8 for adherence. Total score were translated into 3 category, they were high adherence (score 8), medium adherence (score 6 to $<8$ ), and low adherence ( score $<6$ ).

Clinical outcome was assed by blood pressure measure using digital blood pressure device. The outcome was recorded as systol and diastol. The number was used to interpret clinical outcome to adherence scale.

Quality of life was measured by EQ-5D-3L consist of 5 dimensions (mobility, self-care, usual activities, pain/ discomfort, and anxiety/ depression), and has 3 levels (no problems, some problems, and extreme problems) of each dimension. Health state was converted to utility score. EQ-5D index score was measured using UK value set [17]. Utility range of EQ-5D from 0.0 (the worst health) to 1.0 (the best health).

\subsection{Data analysis}

The correlated data were adherence versus clinical outcome and adherence versus quality of life. The value of systolic and diastolic blood pressure were obtained by the mean of blood pressure measurements. EQ-5D-3L assessment was performed by precentage of quality of life. Furthermore, data analysis was displayed using SPSS version of 22 by Spearmen rho test.

\section{Result and Discussion}

Patients who participated in the study consisted of 24 men and 36 women. Characteristic of patients are shown in Table 1. 
Table 1. Patient Characteristics

\begin{tabular}{llcc}
\hline \multirow{2}{*}{ Characteristic } & \multicolumn{2}{c}{ Total } \\
\cline { 3 - 4 } & & $\mathrm{n}(60)$ & $\begin{array}{c}\text { Perscentage } \\
(\%)\end{array}$ \\
\hline \multirow{2}{*}{ gender } & Man & 24 & 40 \\
& Women & 36 & 60 \\
\hline \multirow{3}{*}{ Age (years) } & $36-45$ & 6 & 10 \\
& $46-55$ & 17 & 28 \\
& $56-65$ & 25 & 42 \\
\multirow{3}{*}{ Level of education } & $>65$ & 12 & 20 \\
\hline \multirow{5}{*}{ Occupation } & junior high school & 2 & 3 \\
& senior high school & 28 & 47 \\
& bachelor & 30 & 50 \\
\hline & Unemployed & 1 & 2 \\
& Entrepreneur & 20 & 33 \\
& Housewife & 15 & 25 \\
& Officer & 14 & 23 \\
& Pensionary & 10 & 17 \\
\hline
\end{tabular}

By the age, $42 \%$ patients were 56-65 years old and half of respondents graduated from universities. Overall women had higher admissions (60\%) compare to those man (40\%). By the gender, the result in accordance with Peltzer and Pengpid (2018), 31.0\% experienced by men and 33.4\% in women [18]. Otherwise, Everett and Zajacova (2015) found that women was less likely affected of hypertensive (12\%) compared those to men (27\%) [19]. There are many factors affected hypertension prevalence, as psychological, life styles, social support, economic factor and others are also relevant to change the hyepertension state [20].

With regard to adherence, almost patients had a low adherence (52.6\%) with blood pressure mean of $156 / 90 \mathrm{mmHg}$. Only $22.8 \%$ of patients were highly adherence. Table 2 displyed the correlation of adherence with clinical outcomes.

Table 2. Correlation of Adherence with Clinical Outcomes

\begin{tabular}{|c|c|c|c|c|}
\hline \multicolumn{5}{|c|}{ Correlations } \\
\hline & & & $\begin{array}{c}\text { Adherence } \\
\text { score }\end{array}$ & Outcome \\
\hline \multirow{6}{*}{ Spearman's rho } & \multirow{3}{*}{ Adherence score } & $\begin{array}{l}\text { Correlation } \\
\text { Coefficient }\end{array}$ & 1.000 & \\
\hline & & Sig. (2-tailed) & & .000 \\
\hline & & $\mathrm{N}$ & 60 & 60 \\
\hline & \multirow{3}{*}{ Outcome } & $\begin{array}{l}\text { Correlation } \\
\text { Coefficient }\end{array}$ & $-.745^{* *}$ & 1.000 \\
\hline & & Sig. (2-tailed) & .000 & \\
\hline & & $\mathrm{N}$ & 60 & 60 \\
\hline
\end{tabular}

Based on statistical analysis, adherence has a significant relationship to clinical outcomes $(p<0.05)$ with a strong correlation of $r=-0.745$. The correlation coefficient was negative referred to adherence and clinical outcomes has an inverse correlation, in case adherence decreases, blood pressure become increase that indicated the decrease in clinical outcomes. There are many factors affected the adherence of patients to take medication. According to Mekonnen et al. (2017) study, patients who had experienced three or more years on taking antihypertensive 
medication had two times more likely adhere compared to those patients with less than three years. In developing countries, patients with high adherence were the most important challenge to maintan their adherence understanding [21]. Mouraet al. (2016) reported that personal reasons become the highest factors (70.3\%) contributed to non-adherence, while nonpharmacological dan pharmacological treatment contributed at $15.9 \%$ nd $21 \%$, respectively [22]. The global burden of hypertension described systolic blood pressure $\geq 140 \mathrm{mmHg}$ and diastolic blood pressure $\geq 90 \mathrm{mmHg}$ or antihypertensive treatment was estimated to increase from 918 million in year 2000 to 1.56 billion in 2025 [23]. Based on Table 3, patient's quality of life was $77.7 \%$.

Table 3. Correlation of Adherence with Quality of Life

\begin{tabular}{|c|c|c|c|c|}
\hline \multicolumn{5}{|c|}{ Correlations } \\
\hline & & & $\begin{array}{l}\text { Adherence } \\
\text { score }\end{array}$ & $\begin{array}{c}\text { Utilit } \\
y \\
\text { index }\end{array}$ \\
\hline \multirow{6}{*}{ Spearman's rho } & \multirow{3}{*}{ Adherence score } & $\begin{array}{l}\text { Correlation } \\
\text { Coefficient }\end{array}$ & 1.000 & $.554^{* *}$ \\
\hline & & Sig. (2-tailed) & & .000 \\
\hline & & $\mathrm{N}$ & 60 & 60 \\
\hline & \multirow{3}{*}{ Utility index } & $\begin{array}{l}\text { Correlation } \\
\text { Coefficient }\end{array}$ & $.554^{* *}$ & 1.000 \\
\hline & & Sig. (2-tailed) & .000 & \\
\hline & & $\mathrm{N}$ & 60 & 60 \\
\hline
\end{tabular}

**. Correlation is significant at the 0.01 level (2-tailed).

Only $1.8 \%$ of the anxiety or depression was the extremely problems for quality of life dimension. Adherence has a relationship to quality of life $(\mathrm{p}<0.05)$ with moderate correlation $r=0.554$. Correlation coefficien was positive, showed that the higher of adherence, the better of quality of life. The result also supported by previous study, a positive correlation was detected in adherence and quality of life, however the study has a strong correlation [24]. This was probably due to the differences of hypertension stage observed. The study at Cumhuriyet University Hospital revealed the positive correlation of adherence and quality of life on physical and mental health which mental health score was higher than the physical score [24]. Otherwise, Souza et al (2016) in a systematic review of hypertensive patients revealed the physical score health was higher than mental score [25]. A cross-sectional study in Alwatani Hospital-Palestine revealed the high adherence (evaluated by MMAS) showed the higher quality of life score (evaluated by the EQ-5D) [26]. The poor quality of life was associated with low adherence for numerous reasons including psychosocial well-being and the attitude of hypertensive patients toward taking medications [27]. Overall, adherence as a promoting factor for quality of life in pharmacological treatment provided the awareness of hypertensive patients to chase the health behaviour [25].

For further research, needed to emphasize the patients adherence for improving clinical outcomes and quality of life. 


\section{Conclusion}

This study concluded that adherence has a correlation with clinical outcomes and the quality of life of primary hypertension patients.

\section{Acknowledgement}

The authors are grateful thank to Faculty of Pharmacy, Universitas Sumatera Utara for the facilities support.

\section{REFERENCES}

[1] Ministry of health of Indonesia. Indonesia health profile 2016. Jakarta: Data and Information Center of the Health Ministry of Republic of Indonesia, 2017. 102p.

[2] WHO. Global Status Report on Noncommunicable Diseases. Switzerland: WHO, 2014. xiv p.

[3] PERKI. Guidelines for management of dyslipidemia. Jakarta: Centra Communications, 2017. 10-14 p.

[4] Ministry of health of Indonesia. Health Research 2018, Jakarta: Health Ministry of Republic of Indonesia, 2018. 156-160 p.

[5] M.T. Brown, J. Brussell, S. Dutta, K. Davis, S. Strong, S. Mathew. "Medication Adherence: Truth and Consequences," The American Journal of the Medical Sciences, vol. 351, no. 4, pp. 387-399. 2016.

[6] A.P.F. Maciel, H.B. Pimenta, A.P. Caldeira. "Quality of life and medication adherence in hypertensive patients," Acta Paul Enferm, vol. 29, no. 5, pp. 542-548. 2016.

[7] C.D. Barbosa, M.M. Balp, K. Kulich, N. Germain, D. Rofail. "A Literature Review to Explore the Link between Treatment Satisfaction and Adherence, Complience, and Persistence." Patient Preference and Adherence, vol. 6, pp. 39-48. 2012.

[8] G.U. Iloh, A.N. Amadi. "Treatment Satisfaction, Medication Adherence, and Blood Pressure Control among Adult Nigerians with Essential Hypertension," International Journal of Health \& Allied Sciences, vol. 6, no. 2, pp. 75-81. 2017.

[9] H. G.S. Femida, E. Manias, L. Lal, M. Salas, D.A. Hughes, A. R. Leewing, M. Grubisic. "Impact of Interventions on Medication Adherence and Blood Pressure Control in Patients with Essential Hypertension: A Systematic Review by the ISPOR Medication Adherence and Persistence Special Interest Group," Value Health, vol. 16, no. 5, pp. 863-871. 2013.

[10] O. Amaral, C. Chaves, J. Duarte, E. Countinho, P. Nelas, O. Preto. "Treatment Adherence in Hypertensive Patients-A Cross-sectional Study," Sociall and Behavioral Sciences, vol. 171, pp. 1288-1295. 2014.

[11] M. Burnier. "Drug Adherence in Hypertension," Pharmacological Research., vol. 125, pp. 142-149. 2017.

[12] S. Boratas, H.F. Kilic. "Evaluation of Medication Adherence in Hypertensive Patients and Influential Factors," Pakistan Journal of Medical Sciences. Vol. 34, no. 4, pp. 1-5. 2018.

[13] B. Uchmanowicz, A. Chudiak, G. Mazur. "The influence of quallity of life on the level of adherence to therapeutic recommendations among elderly hypertensive patients", Patient Preference and Adherence, vol. 12, pp. 2593-2603. 2018.

[14] M. Amer, N. U. Rahman, S.U.R. Nazir, A. Raza, H. Riaz, M. Sultana, S. Sadeeqa. "Impact of Pharmacist's Intervention on Disease Related Knowledge, Medication Adherence, HRQoL and Control of Blood Pressure Among Hypertensive Patients," Pak. J. Pharm. Sci, vol. 31, no. 6, pp. 2607-2616. 2018.

[15] Q. Yao, C. Liu, Y. Zhang, L, Xu. "Health-Related Quality of Life of People with SelfReported Hypertension: A National Cross-Sectional Survey in China," International Journal of Environment Research and Public Health, vol. 16, no. 72, pp. 1-24. 2019.

[16] D.A. Riani, Z. Ikawati, S.A. Kristina. "Validasi 8-item Morisky Medication Adherence 
Scale versi Indonesia pada pasien hipertensi dewasa di puskesmas kabupaten Sleman dan kota Yogyakarta," Tesis, Universitas Gadjah Mada, 2017.

[17] EuroQol Research Foundation. EQ-5D-3L User Guide. Basic Information on How to Use the EQ-5D-3L Instrument. Netherlands: Euroqol. 2018; 7-14 p.

[18] K. Peltzer, S. Pengpid. "The prevalence and social determinants of hypertension among adults in Indonesia: a cross-sectional population-based national survey," International Journal of Hypertension, pp.1-9. 2018.

[19] B. Everett, A. Zajacova. "Gender differences in hypertension and hypertension awareness among young adult," Biodemography Soc. Biol, vol. 61, no. 1, pp. 1-17. 2015.

[20] S.S.B.E. Silva, S.F.S.B. Oliveira, A.M.G. Pierin. "The control of hypertension in men and women: a comparative analysis," Journal of School of Nursing USP, vol. 5, no. 1, pp.50-58. 2016.

[21] H.S. Mekonnen, M.H. Gebrie, K.H. Eyasu, A.A. Gelagay. "Drug adherence for antihypertensive medications and its determinants among adult hypertensive patients attending in chronic clinics of referral hospitals in Northwest Ethiopia," BMC Pharmacology and Toxicology, vol. 18, no. 27, pp. 1-10. 2017.

[22] A.A. Moura, S. Godoy, C.B. Cesarino, I.A.C. Mendes. "Factor determinig nonadherence to hypertension treatment," Enfermerfe Global, pp. 27-39. 2016.

[23] M. Burnier, B.M. Egan. "Adherence in Hypertension, A Review of Prevalence, Risk Factors, Impact, and Management," AHAjournal, pp.1124-1140. 2019.

[24] M. Mollaoglu, G. Solmaz, M. Mollaoglu. "Adherence to therapy and quality of life in hypertensive patients," Acta Clin Croat, vol. 54, pp.438-444. 2015.

[25] A.C.C. Souza, J.W.P. Borges, T.M.M. Moreira. "Quality of Life and Treatment Adherence in Hyertensive Patientss: systematic review with meta-analysisis,"Revista de Saude Publica, vol. 50, no. 71, p. pp. 1-14. 2016.

[26] S.H. Zyoud, W. Al-Jabi, W.M. Sweileh, A.H. Wildali, H.M. Saleem, H.A. Aysa, M.A. Badwan, R. Awang, D.E. Morisky. "Health-related Quality of Life Associated with Treatment Adherence in Patients with Hypertension: A Cross-Sectional Study," International Journal of Cardiology, vol. 168, no. 3, pp. 2981-2983. 2013.

[27] E.W. Holt, P. Muntner, C.J. Joyce, L. Webber, M.A.K. Wood. "Health-related Quality of Life and Antihypertensive Medication Adherence among Older Adults," Age and Ageing, vol. 39, pp. 481-487. 2010. 